\title{
PHYTOCHEMICAL AND ANTIOXIDANT SCREENING OF CASSIA ANGUSTIFOLIA, CURCUMA ZEDOARIA, EMBELIA RIBES, PIPER NIGRUM, ROSA DAMASCENA, TERMINALIA BELERICA, TERMINALIA CHEBULA, ZINGIBER OFFICINALE AND THEIR EFFECT ON STOMACH AND LIVER
}

\author{
Umar Zeeshan, Muhammad Qasim Barkat*, Hafiz Khalid Mahmood \\ Institute of pharmacy, physiology and pharmacology, University of Agriculture, Faisalabad \\ *Corresponding Auhtor email: dr.umarz@hotmail.com, qasimbarkat07@gmail.com, khalid2899@yahoo.com
}

This is an open access article distributed under the Creative Commons Attribution License, which permits unrestricted use, distribution, and reproduction in any medium, provided the original work is properly cited.

\section{ARTICLE DETAILS}

\section{Article History:}

Received 25 November 2017 Accepted 26 December 2017 Available online 1 January 2018

\section{ABSTRACT}

Herbal medicinal natural plants and species are mostly used for wide purposes in Pakistan in current situation. There are diverse variety of phytochemical constituents which are present in plants and act as secondary metabolites that are formed from the normal metabolism likewise alkaloids, flavonoids, glycoside, phenols, steroids and other specific pigments. Therefore, the botanist concentrations are increasingly changing to ethnobotanical practices due to availability at lower price, wide safety and efficacy margin and less side effects of plants. The medicinal benefits of the special phytochemical of the plants cannot be ignored. Some of the herbal plants have been expressed for their significance to take care of the different ailments of mankind particularly correlated to liver, GIT, stomach and colon.

\section{KEYWORDS}

Metabolites, alkaloids, flavonoids, glycoside, phenols, steroids.

\section{INTRODUCTION}

Now days, Medicinal plants and spices are cultivated and replacing conventional crops in Pakistan [1]. Usage of natural plants or any part of plants particularly certain herbs in the remedy of specific disorders or conditions is lie under the category of Ethnomedicines. Pakistan is one of the known countries for production and usage of these medicinal plants [2]. World health Organization (WHO) expected that there are about $80 \%$ of the world population mainly depend on the ethnomedicines in favor of their crucial health requirements rather than allopathic medicines in the developing countries [3]. Human beings have been used medicinal plants in curing various disorders and ailments because these plants seem to be less toxic and also have no significant side effects [4]. In some study explained that phytochemicals are present in plants which are secondary metabolites and produced as a result of normal metabolism of these medicinal plants such as phenols, alkaloids, steroids, glycosides, flavonoids and certain pigments [5]. Reactive oxygen species (ROS) are highly reactive molecules containing unpaired electrons and produced by living organisms under normal cellular metabolism and environmental factors. These molecules at low to moderate concentration are responsible of cell signaling and normal physiological processes, but at high concentration, they produce adverse modifications to the cellular components. In this review paper, the product of existing ethnomedicine consists of the extracts of plants that are investigated as phytochemical (qualitatively and quantitatively) and ROS status of plants. This project has not been only helped to understand the compositional integrity of the ethnomedicine but also gave a deep insight into the effectiveness of specific phytochemicals which were the essential part of these medicinal plants. Cassia angustifolia, Curcuma zedoaria, Embelia ribes, Piper nigrum, Rosa damascena, Terminalia belerica, Terminalia chebula and Zingiber officinale have been reviewed for the treatment of human disorders likewise stomach, liver and other ailments.

\section{CASSIA ANGUSTIFOLIA}

A study stated that Cassia angustifolia also known as Senna Alexandria is an ornamental plant [6]. It belongs to family Leguminosae, widely cultivated in India and South East Asia and is commonly known as sarakonarai in Tamil. A researcher concluded that Cassia angustifolia has been used as laxative agent because it contains hydroxyanthracene glycosides which increase the peristaltic movement of colon and also alters its absorption and resulting in fluid accumulation and expulsion of excreta [7]. A group researchers revealed that Cassia angustifolia has antibacterial, hypo-chlosterolaemic, hepato-protective, anti-diabetic, antiinflammatory and anti-oxidant actions. Cassia angustifolia also performs hepato-protective functions by restoring the elevated level of serum marker enzymes which in case of liver damage is decreased due to the loss of hepatocytes integrity. A group researchers also explained that increased level of serum bilirubin is also indicator of hepato-cellular damage but when treated with Cassia angustifolia these patients show significant reduction in conjugated and un-conjugated level of bilirubin by improving the liver conjugation function by activating the androstane receptors which helps in bilirubin clearance from liver [8]. A group scientist revealed that Cassia angustifolia also shows anti-hyperglycemic effect and can be used in diabetic patients [6]. Diabetes mellitus is basically irreversible damages to the beta cells resulted in reduction of insulin production, this low insulin production increases the activity of fatty acetly CoA enzyme which start beta oxidation of fatty acids ultimatly increase lipid peroxidation which impairs the membrane integrity and produce free radicals, while extracts of Cassia angustifolia increase the anti-oxidant activity of some enzymes.

Cassia anugustifolia shows negative effects on coagulation of blood and may be associated with venous thrombosis [9]. A group researchers concluded that excessive use of Cassia anugustifolia can cause some side effects including chronic diarrhea with fluid and electrolyte loss which leads to dehydration [10]. Denninger and Marletta, determined that as a 
laxative agent abuse of Cassia anugustifolia may cause hepatotoxicity so careful use is more necessary for Cassia angustifolia [11]. Cassia angustifolia seeds gum have the potential to convert into a new source of commercial gum thus utilized as an additive in pharmaceutical formulations [12]. Phytochemical qualitative and quantitative analysis of cassia angustifolia have been reported in the table 1 and 2 .

\section{CURCUMA ZEDOARIA}

Curcuma zedoaria belongs to the family Zingiberacae also called zinger family and commonly known as white turmeric. Curcuma zedoaria has 70 species most of them have been used in traditional medicines from many eras. In Pakistan, Curcuma zedoaria is mostly found in Sahiwal, Kasur and Okara in Punjab and Bannu, Harripur areas in Khyber Pakhtunkhwa [13].
The major constituents of Curcuma zedoaria which reveals the pharmacological activities are terpene compound, including anodiene, curdione, curcumenol, curcumenon and curcumin. Curcuma zedoaria has a great scavenging and reducing effects against 2,2-diphenyl-1picrylhydrazyl (DPPH) but low in chelating effect on ferrous ion [14]. The scavenging effect of essential oils present in Curcuma zedoaria on DPPH radical is directly proportional to the concentration of these oils. At $20 \mathrm{mg} / \mathrm{ml}$ the scavenging effect of essential oils was $96.8 \%$ as comparable to butylated hydroxyanisol (BHA) that was $97 \%$ and alph-tocopherol (96.4) and higher than that of ascorbic acid (92\%). The scavenging effects of BHA, alpha-tocopherol and ascorbic acid were more effective at extremely low dose than that of essential oils of Curcuma zedoaria depending upon the concentration [15].

Table 1: Qualitative Analysis of plant extracts used in Habb-E-Kabid Naushadari.

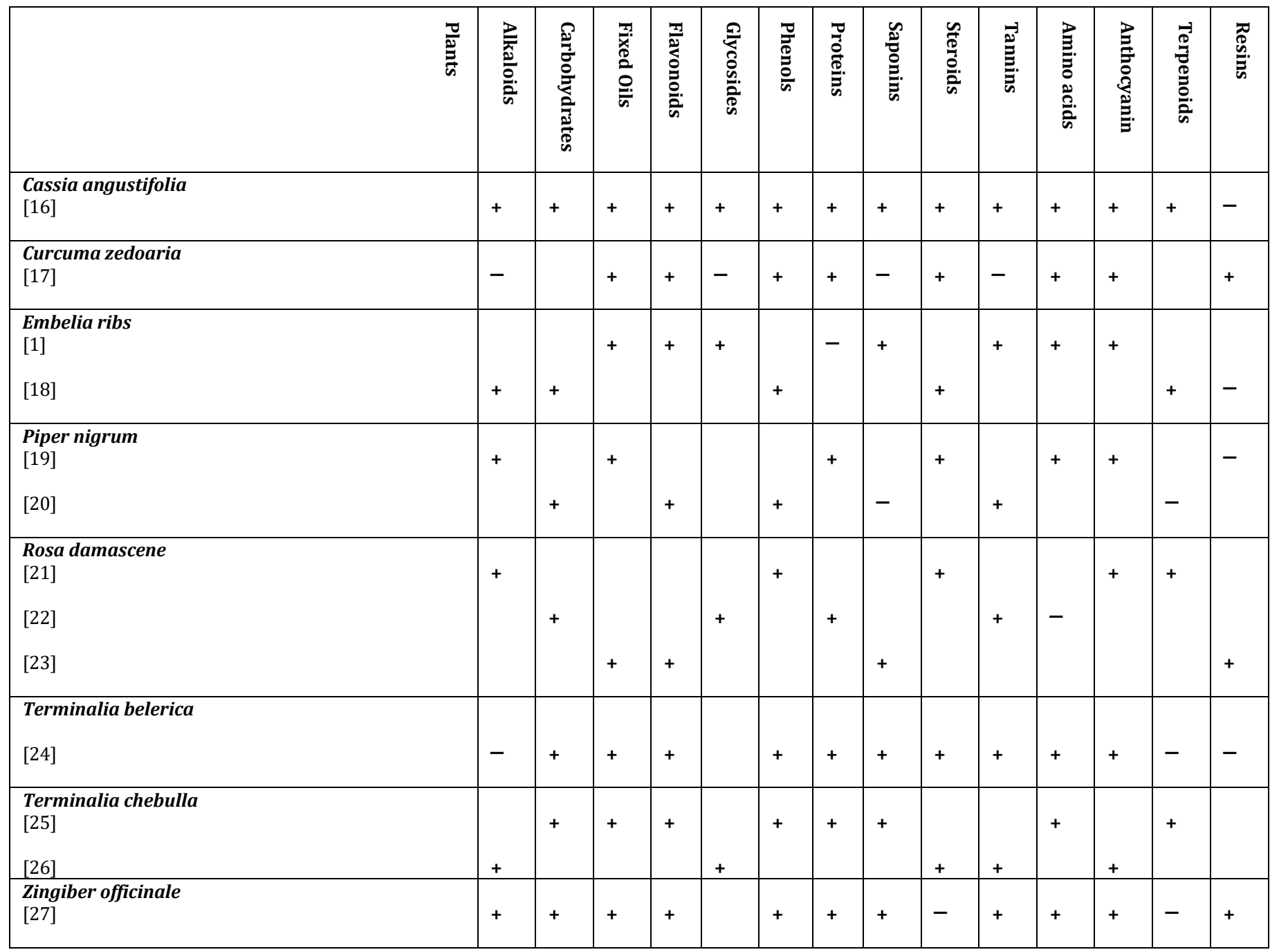

+ : Indicate positive test

- : Indicate negative test

Table 2: Quantitative Analysis of plant extracts used in Habb-E-Kabid Naushadari.

\begin{tabular}{|c|c|c|c|c|c|c|}
\hline & $\frac{\overline{0}}{2}$ & 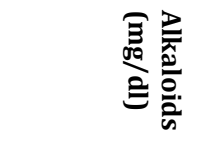 & 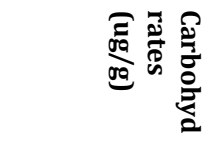 & 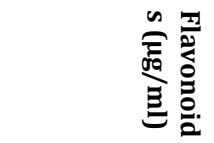 & 高 & 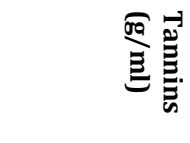 \\
\hline $\begin{array}{l}\text { Cassia angustifolia } \\
{[28]}\end{array}$ & & 24.6 & 26.3 & 6.35 & N.A & N.A \\
\hline $\begin{array}{l}\text { Curcuma zedoaria } \\
\text { [17] }\end{array}$ & & N.A & 34 & N.A & N.A & N.A \\
\hline $\begin{array}{l}\text { Piper nigrum } \\
{[20]}\end{array}$ & & 156.8 & 46.1 & 1.08 & 261.4 & 0.002 \\
\hline $\begin{array}{l}\text { Rosa damascene } \\
{[21]}\end{array}$ & & N.A & 54 & 16 & N.A & N.A \\
\hline $\begin{array}{l}\text { Terminalia belerica } \\
{[24]}\end{array}$ & & N.A & 29 & 0.42 & 29.6 & N.A \\
\hline
\end{tabular}




\section{- N.A: Indicated as Not Analyzed}

It has been used as hepatoprotective, anti-mutagenic, anti-carcinogenic against human ovarian cancer cell lines, anti-oxidant, anti-inflammatory and anti-microbial. A group researchers investigated that a special compound found in Curcuma zedoaria called curcuminoid has the inhibitory role against HIV Type-1 integrase which is one of the important functions of Curcuma zedoaria in modern medication [14]. Essential oils present Curcuma zedoaria play a vital role as an anti-oxidants and the compound responsible for the activity might be Azulenone. Phytochemical qualitative and quantitative screening of Curcuma zedoaria have been reported in the table 1 and 2 .

\section{EMBELIA RIBES}

In a study, stated that Embelia ribes is a woody shrub belongs to family Myrsinaceae and it is widely distributed in the deciduous moist forests of India, Sri Lanka, South China and Western Ghats [29]. Embelia ribes is a shrub and found in hilly areas and commonly named as Vidanga or Bashmak. Other researchers described that Embelia ribes has active component embolin (embolic acid) along with Embelia ribes has also alkaloids, phenolics, saponins and carbohydrates [30]. Some of the researchers determined that Embelia ribes increases the activity of antioxidants and prevented the myocardial degeneration and also evaluated wound healing activity of Embelin isloated from ethanolic extracts of leaves of Embelia ribes [19]. A group researchers proved that Embelia ribes also shows anti-arthritis effects Embelia ribes lowers the interleukin $1 \beta$ and tumor necrosis factor $\alpha$ and enhanced immune-modulatory effects on humoral and cellular immune responses [31]. Embelia ribes also lower the skin inflammation by inhibiting the tumor necrotic factor alpha (TNF $\alpha$ ) and by reducing the skin thickness.

Sreepriya and Bali, explained that Embelin provide protection to the hepatic cell by scavenge the free radicals and lowering the lipid per oxidation which causes the damage to the liver [32]. Embelia ribes also have anti-tumor activity by blocking the nuclear kappa factor blocking pathway which block the production of cancer producing genes. Some researchers investigated that Embelia ribes is being used as potent antioxidant in diabetic patients [33]. Seeds of Embelia ribes contain somehow bitter taste and used in treatment of ascites, mental distress, tumors, heart diseases, urinary discharges, snake bite. In mammalian cell line, it is being used as anti-inflammatory, anti-cancerous, chemo preventive, anti-oxidant and hepatoprotective agent.

A group researchers stated that islet beta-cells of pancreas are more susceptible to damage caused by oxygen free radical since defensive system against reactive oxygen species become weak under diabetic conditions [34]. Increased serum lactate dehydrogenase (LDH) and creatinine phospsokinase (CPK) levels in diabetic patients indicate cardiac muscular damage. Amount of these two hormones quantify the number of necrotic cells in the damaged tissue since both these parameters directly correlate with each other. Treatment with the ethanolic extracts of Embelia ribes continuously not only maintain the serum level of both parameters but also helping in the treatment of pancreatic disease [35]. Ethanolic extracts of Embelia ribes have the potency to reduce the nephrotoxicity in type-II diabetes by maintaining the hypertension and blood glucose level which are the main cause of nephrotoxicity in this condition. Hyperglycemia induced various signaling pathways activation which leads to increased level of reactive oxygen species. These reactive oxygen species (ROS) severely damaged the kidney at cellular level. The islets of beta-cells are more susceptible to ROS and free radicals under diabetic condition [36]. Phytochemical qualitative study of Embelia ribes have been given in the table 2 .

\section{PIPER NIGRUM}

Piper nigrum belongs to the family Piperaceae which comprises of 12 genera and about 1400 species mainly found in tropical areas. Commonly it is known as Kalimirch, Kalimari and Black Pepper. Piper nigrum is aromatic plant and most commonly used spice and regarded as king of spices [37]. Piper nigrum located in Indo-Malays region and mostly found in lower hills of West Bengal [38]. Some study mentioned that Piper nigrum was grown in tropical and subtropical rain forest and important medicinal and economical plant in various systems of medicine in South India due to its multi-dimensional effects [39].

Kaefer and Milner, determined that when triglycerides with oxidative stress and cholesterol levels high then they inhibit or block the activity of major antioxidants as catalase, glutathione, vitamin E (tocopherol), vitamin C (ascorbic acid), superoxide dismutase and glutathione peroxidase and Piper nigrum maintains the improvement of these antioxidants levels in the body [40]. Suhaj, explained that best and more significant method to cover the bad flavour of meat products [41].

A group scientist described that Piper nigrum used in different conditions like in indigestion, anorexia, flatulence, cholera, malaria, arthritis, fever, vertigo, coma, sore throat and skin problems [42]. Piper nigrum also increases the loss of potassium and pepsin secretion in parietal cells. Piper nigrum also has anti-oxidant and anti-ulcer treatment therapy for these ailments.

Piper nigrum dilates the skin superficial vessels and prevents from fever when taking high doses. Piper nigrum also acts as stimulant and prevents from fever in malaria therefore used as anti-pyretic and anti-inflammatory [30]. Piper nigrum has carminative and stimulating characteristics which causing the flow of saliva reflux that increases the gastric juices secretion and improves the appetite. Piper nigrum also helps in the treatment of indigestion, dysentery, stomach chills and diarrhea and has also used to be supportive therapy in gas eructation and colic problems [43].

Karsha and Lakshmi determined that Piper nigrum has potent antimicrobial activity against gram positive and gram-negative bacteria [44]. Piper nigrum inhibits the growth of Staphylococcus aureus, Bacillus cereus and Streptococcus faecalis in gram positive bacteria but in gram negative bacteria Piper nigrum inhibits the growth of Pseudomonas aeroginosa, Salmonella typhae and Escherichia coli. Piper nigrum also helps in many other problems likewise in vertigo, asthma, chronic indigestion, colonic toxin, obesity, sinusitis, fever, paralysis, arthritis, diarrhea and cholera. Platel and Sirivansan, described the uses of Piper nigrum to be antiinflammatory, anti-pyretic, diuretic, immune-stimulant, hepatoprotective, anti-oxidant, anti-microbial, rubefacient, counter irritant, anti-septic, digestive, analgesic, and anti-spasmodic [45]. Many of these therapeutic activates of Piper nigrum are associated with the piperine which is a major alkaloidal component of Piper nigrum.

Some researchers estimated high level of phytochemicals present in the Piper nigrum such as phenolic and alkaloids metabolites are responsible for the anti-microbial activity [46]. These metabolites show the antimicrobial activity by interfering the growth and metabolism of the microorganisms. As mentioned in a study that piperine is the alkaloidal component of Piper nigrum which is responsible for most of the antimicrobial, anti-septic, anti-inflammatory and anti-pyretic functions [47]. The free radical scavenging activity of ethanolic extracts of Piper nigrum was evaluated using the 2,2-diphenyl-1-picrylhydrazyl (DPPH) assay (250 microg/ml) which shows a good anti-oxidant activity against reactive oxygen species [48]. A group scientist have been referred that Piper nigrum also responsible for the abnormal physiological and behavioral activities like hypoactivity, hyperactivity, sedation, erection of tail and body hairs, shivering of body, increase and decrease of activity [49]. Phytochemical (Qualitative and Quantitative) and ROS of Piper nigrum have been reported in the table 1,2 and 3.

Table 3: In vivo anti-oxidant activity of plants used in Habb-E-Kabid Naushadari.

\begin{tabular}{|l|l|l|l|}
\hline Parameters & $\begin{array}{l}\text { Superoxide } \\
\text { Dismutase } \\
\text { (U/g) }\end{array}$ & $\begin{array}{l}\text { Catalase } \\
\text { (kU / L) }\end{array}$ & $\begin{array}{l}\text { Glutathione } \\
\text { (milliunits/mg) }\end{array}$ \\
\hline $\begin{array}{l}\text { Zingiber officinale } \\
{[49]}\end{array}$ & $620 \pm 22.56$ & $2.51 \pm 0.49$ & $218.30 \pm 46.2$ \\
\hline $\begin{array}{l}\text { Piper nigrum } \\
{[50]}\end{array}$ & $17.20 \pm 3.06$ & $0.161 \pm 0.017$ & $0.154 \pm 0.014$ \\
\hline
\end{tabular}

U: Enzyme activity or units (U) is the amount of enzyme that converts one micro mole of substrate per minute, $1 \mathrm{U}=1 / 60$ micro katal = 16.67 nano katal.

\section{ROSA DAMASCENA}

Rosa damascena is deciduous shrub of family Rosaceae having beautiful flowers which are used all over the world for visual beauty and scents. Lobster, described that Rosa damascena is cultivated throughout the world particularly in Iran for visual beauty and medicinal uses [51]. A group researchers investigated that Rosa damascena was used to treat abdominal pain, chest pain, menstrual bleeding, anti-inflammatory and in digestive problems previously [52]. Oils of this plant have analgesic, antiinflammatory, anti-spasmodic and hypnotic effect. Rosa damascena shows antioxidant property by peroxidation of linoleic acid. Lobster, investigated that Rosa damascena has protective effect on liver and reduced parasitamol liver damage [52]. 
Other researchers explained that Rosa damascene contains certain phytochemical metabolites including carboxylic acid, terpene, myrcene and vitamin $\mathrm{C}$ which are responsible for most of the beneficial activities of Rosa damascene [53]. Kazaz and them collogues reviewed that parts of Rosa damascena have carbohydrates $34 \%$, proteins, alkaloids, saponins, fats and oils and phenolic compounds [21]. Most of medicinal properties of Rosa damascena are due to these compounds.

Some researchers described that aqueous and ethanolic extracts of rose oils and petals reflected wide spectrum anti-bacterial action which was more detrimental towards gram-positive bacteria tha gram-negative bacteria [54]. While anti-fungal activity of Rosa damascena extracts also examined against yeast and molds with diameter of zones of inhibition ranged between 10.5 to $17.5 \mathrm{~mm}$ produced by disc diffusion assay. Phytochemical qualitative and quantitative investigations of Rosa damascena have been found in the table 1 and 2 .

\section{TERMINALIA BELERICA}

Terminalia belerica also referred to as Bahera or Beleric Myrobaham belongs to family Combretaceae. Terminalia belerica is growing widely throughout the Sri Lanka, South East Asia and Indian subcontinent and its fruits specifically used for medicinal purposes. Acute and sub-acute toxicities, anti-oxidant, anti-microbial, anti-diabetic, anti-cancer, antidiarrheal, anti-hypertensive and hepatoprotective activities of Terminalia belerica, hence Terminalia belerica can play a vital role in prevention and curing the diseases [3].

A group researchers investigated and concluded the diverse pharmacological spectrum of Terminalia belerica is due to presence of important phytochemical like tannic acid, ellagic acid, gallic acid, flavone, glucose, fructose, and phenyllemblin [55]. Alam investigated that methanolic extracts of Terminalia belerica fruits along with its phytochemical exhibit's antioxidant as well as antibacterial activity [53]. Sabu and Kuttan, has concluded significant increased level of antioxidant enzymes such as glutathione reductase, catalase and superoxide dismutase and decreased level of glucose were observed in blood and liver by using Terminalia belerica which also represents its antioxidant as well as hypoglycemic significance [56]. Phytochemical qualitative and quantitative examination of Terminalia belerica have been evaluated in the table 1 and 2 .

\section{TERMINALIA CHEBULA}

A group researchers considered Terminalia chebula a valuable and noticed that Terminalia chebula is evergreen flowering plant of family Combretaceae [57]. Commonly it is known as black myobaham, ink tree or chebulic myobaham. It is prominently found in Asia, but also found in Nepal, Sri Lanka, Bangladash, Turkey, Iran, Pakistan and tropical areas of the globe. In Hindi this plant is known as harad. Some researchers in their review stated that plants are used for treatments since centuries ago and Terminalia chebula is known as "King of Medicines" as its usage as components in many medicines for treatment of diseases [58].

Moghimipour and Handali, stated that fruits of Terminalia chebula have mild laxative and antispasmodic effects and used in treatment of gastric disturbances and ulcers, dental caries, opthalimia, bleeding gums, ulcered oral cavity and have analgesic effects [59]. Gupta, it shows anti protozoal, wound healing ability, purgative action, antiviral, molluscicidal, antifungal, anti-plasmodial and ant- arthritic activity [57]. A group researhcers described that gall extract of Terminalia chebula is used as medicine and it shows anti-inflammatory, anti-bacterial, anti-cancer anti-tyrosinase and anti-aging activities [60]. Anti-bacterial activity of Terminalia chebula is due to presence of anti-mycobacterial antibacterial agents as ellagitannins, ellagic acid derivates, gallo tannins and condensed tannins. Lee and his group have investigated that anti-oxidant property of Terminalia chebula is due to the presence of high amount of phenolic and flavonoid components in ethanolic extracts which help in redox reactions and play a significant role in chelating the transitional metals and scavenging free radicals such as DPPH [61]. Fruits of Terminalia chebula have laxative and antispasmodic effect [60]. Phytochemical qualitative scrutiny of Terminalia chebula has been investigated in table 1 .

\section{ZINGIBER OFFICINALE}

Shukla and Singh stated that Zingiber officinale is a flowering plant belongs to tropical and subtropical family Zingiberaceae. Zingiber officinale was originated from South East Asia and introduced to the whole globe [62]. Ali and his collogues found that Zingeber officinale mostly contains monoterpenoids volatile oils such as beta phellandrene, camphene, curcumene, cineol, gerniol, gingerol, shogaols, terpineol and sesquiterpenoids as alpha zingiberene (30-70\%), zingiberol, beta sesquiphellandrene (15-20\%) and beta bisbabolene (10-15\%) which are responsible of most of beneficial activities of Zingeber officinale [63]. Zingiber officinale is used as flavoring ingredients in India and China for making many dishes of meat and vegetables and its rhizome, root and ginger whole is used as spice element in cooking and also as a medicine for treatment of different diseases. Some researchers reported that Zingeber officinale found in three genera but mostly found in Iceland, Asia, and Africa while out of these 3 genera that are mostly found in India and China [64]. Zingeber officinale consists of fifty-three (53) genera and twelve hundred (1200) species.

Tapsell and his group monitored that used for treatment of nervous diseases, constipation, stroke, asthma, diabetes, gingivitis, anti-bacterial, anti-helminthic, anti-emetic, anti-diarrheal and toothache [65]. Wang and Wang determined that Zingeber officinale is also effective in case of dyspepsia, peptic ulcer, gastric and colon cancer [66]. Zingeber officinale also has anti-microbial activity against Pseudomonas aeruginosa, Salmonella typhimurium, Escherichia coli and Candida albicans.

Thakur stated that Zingeber officinale shows anti-inflammatory components which inhibit production of inflammatory cytokines, enzyme prostaglandin synthetase and arachidonate-5-lipoxygenase, nitric oxide and help in treatment of arterial inflammation [67]. It also shows antioxidant effect by lowering lipid peroxidation and elevating the level of anti-oxidant enzymes. Zingeber officinale also lowers the cholesterol level by acting on liver to lower cholesterol synthesis and convert cholesterol into bile salts and increase its elimination through body by fecal excretion. Ghayur and Gilani, explained that Zingeber officinale also acts as hypotensive agent by controlling the blood pressure [68]. Zingiber officinale also has a blood pressure lowering effect which is mediated by blockage of voltage dependent calcium channels. Zingeber officinale is considering as an alternative to conventional anti-emetic drugs. Zingeber officinale is consider a useful herbal medicine having minor side effect e.g. diarrhea in human. Thomson et al., (2002) concluded that Zingeber officinale also possesses effects of blood clotting and can be used as antithrombotic agent. It lowers the thromboxane-B2 (TBX2) and prostaglandin-E2 (PGE2) production and shows antiinflammatory responses.

In a study, narrated that during thermal processing, shogaol formed from gingerol used for pungent smell, while, gingerol to shogaol degradation were $\mathrm{pH}$ dependent but the reverse process is more rapid [63]. Zingeber officinale can be used in constipation, catarrh, asthma, rheumatism, nervous disease, gingivitis, toothache, stroke, hypertention, diabetes and also act as antioxidant, anti-tumorigenic, anti-lipidemic and anti-emetic in post-operative vomiting. Phytochemical qualitative and ROS investigation of Zingiber officinale have been found in the table 1 and 3.

\section{CONCLUSION}

Herbal medicinal natural plants are used as natural remedied for stomach, liver and other ailments through the whole population. Medicinal plants containes phytochemical likewise saponins, alkaloids, phenols and flavonoids constituents, they not only have different beneficial constituents for humankind but also act as natural remedies with no chances of significant side effects and reoccurrence as the allopathic medicines causes the extra side effects and more chances of other stomach and liver problems. Therefore, the world population mostly dependent upon these herbal medicinal plants that used for the treatment of almost all diseases.

\section{REFERENCES}

[1] Asadullah, S., Ramandang, Rajasekharan. 2013. Preliminary phytochemical investigation of Embelia ribs. International Journal of Pharmaceutical Chemistry, 3 (2), 2231-2781.

[2] Kumar, S.P., Rahul, B., Sumit, V., Rashmi, A. 2014. Phytochemical Investigation of Ethanolic extract of Piper nigrum, Zingiber officinale and Allium sativum. International Research Journal of Pharmacy, 5 (11), 814816.

[3] Naga, M.S., Karthikeyan, M., Kannan, M., Rajasekar, S. 2012. Terminalia belerica Roxb-A pharmacological review. International Journal of Pharma and Bio Sciences, 3 (1), 96-99.

[4] Elberry, A.A., Harraz, F.M., Ghareib, S.A., Gabr, S.A., Nagy, A.A., AbdelSattar, E. 2011. Methanolic extract of Marrubium vulgare ameliorates hyperglycemia and dyslipidemia in streptozotocin-induced diabetic rats. International Journal of Diabetes Mellitus, 11, 1877-1878. 
[5] Kumar, R.S., Sivakumar, T., Sundaram, R.S., Sivakumar, P., Nithaji, R., Gupta, M. 2006. Anitimicrobial and Antioxidant Activities of Careya arborea Roxb. Stem Bark. Iran. J. Pharmacol. Ther., 5 (1), 35-41.

[6] Manomani, G., Bhavapriya, V., Kalpana, S., Govindasamya, S., Apparananthamb, T. 2005. Antioxidant activity of Cassia fistula flowers in alloxan induced Diabetic rats. Journal of Ethnopharmacology, 97, 39-42.

[7] Silva, C.R., Monteiro, M.R., Rocha, H.M., Ribeiro, A.F., Caldeira-deAraujo, A., Leit, A.C., Bezerra, A.C., Pádula, M. 2008. Assessment of Antimutagenic and Geno- toxic Potential of Senna (Cassia angustifolia Vahl.) Aqueous Extract Using In vitro Assays. Toxicology in Vitro, 22 (1), 212-218.

[8] Veerabahu, R.M., Shanmugasundaram, R., Devi, V.K., Tresina, P.S., Maruthupandian, A. 2010. Hepatoprotective activity of Ethanol extracts of Clitoria Ternate $\mathrm{L}$. and Cassia angustifolia leaf against $\mathrm{CCl}_{4}$ induced liver toxicity in rats. International Research Journal of Pharmacy, 1, 201- 205.

[9] Prandoni, P., Falanga, A., Piccioli, A. 2005. Cancer and venous thromboembolism. The Lancet Oncology, 6, 401-410.

[10] Stickel, F., Patsenker, E., Schuppan, D. 2005. Herbal hepatotoxicity. Journal of Hepatology, 43, 901-910.

[11] Denninger, J.W., Marletta, M.A. 1999. Guanylate cyclase and the NO/cGMP signaling pathway. Biochimica et Biophysica Acta, 1411, 334350 .

[12] Rajput, G., Pandey, I.P., Joshi, G. 2015. Carboxymethylation of Cassia angustifolia seed gum: Synthesis and rheological study. Carbohydrate Polymers, 117, 494-496.

[13] Akbar, F., Rabbani, M.A., Masood, M.S., Shinwari, Z.K. 2011. Genetic diversity of sesame (Sesamum indicum L.) germplasm from Pakistan using RAPD markers. Pakistan Journal of Botany, 43 (4), 2153-2160.

[14] Mau, J.L., Lin, H.C., Chen, C.C. 2002. Antioxidant properties of several medicinal mushrooms. Journal of Agricultural and Food Chemistry, 50, 6072-6077. [49] Ahmed, K., Gerber, D.A., Cochet, C. 2002. Joining the cell survival squade: an emerging role for protein kinase CK2. Trends in Cell Biology, 12 (5), 226-230.

[15] Ruberto, G., Baratta, M.T. 2000. Antioxidant activity of selected essential oil components in two lipid systems. Food Chem., 69, 167-174.

[16] Shanmugasunadarm, R., Devi, V.K., Tresina, P.S., Maruthupandian, A., Mohan, V.R. 2010. Hepatoprotective activity of ethanol extract of Clitoria ternateal and Cassia angustifolia leaf against $\mathrm{CCL}_{4}$ induced liver toxicity in rats. International Journal of Pharmaceutics, 1, 201-205.

[17] Jatoyi, S., Rajeshwari, S. 2012. Evaluation of phytochemical constituent in conventional and non-conventional species of Curcuma. International Research Journal of Pharmacy, 3 (8), 203-204.

[18] Radhakrishnan, N., Gnanaman, A., Mandal, A.B. 2011. A potential antibacterial agent Embelin, a natural benzoquinone extracted from Embelia ribs. Journal of Biomedicine, 3 (2), 1-7.

[19] Swamy, H.M.K., Krishna, V., Shankarmurthy, K., Rahiman, B.A., Mankani, K.L., Mahadevan, K.M., Harish, B.G., Rajanaika, H. 2007. Wound healing activity of embelinisolated from the ethanolic extract of leaves of Embelia ribes Burm. Journal of Ethnopharmacology, 103 (9), 529-534.

[20] Ahmed, S., Ahmad, M., Ikram, S. 2014. Chitosan: a natural antimicrobial agent - a review. Journal of Applied Chemistry, 3 (2), 493503.

[21] Kazaz, S., Erbas, S., Baydar, H. 2009. The effect of storage temperature and duration on essential oil content and composition of oil rose. Turkish Journal of Field Crops Journal, 14 (2), 89-96.

[22] Schieber, A., Mihalev, K., Berardini, N., Mollov, P., Carle, R. 2005. Flavonolglycosides from distilled petals of Rosa damascena Mill. A. Zeit. Fur. Natr., 5, 379-384.

[23] Kurhade, A.M., Deshmukh, J.M., Fule, R.P., Chande, C., Akulwar, S. 2002. Mycological and serological study of pulmonary aspergillosis in central India. Indian Journal of Medical Microbiology, 20 (3), 141-44.
[24] Yadav, R.N.S., Agarwala, M. 2011. Phytochemical analysis of some medicinal plants. Journal of Phytological Research, 3 (12), 10-14.

[25] Gupta, P.C. 2012. Biological and Pharmacological properties of Terminalia chebula Retz. International Journal of Pharmacy and Pharmaceutical Sciences, 15, 234-237.

[26] Srivastava, P., Raut, H.N., Waugh, R.S., Puntambekar, H.M., Kulkarni, M.J. 2012. Purification and characterization of antioxidant protein (16kD) from Terminalia chebula fruit. International Research Journal of Pharmacy, 131 (1), 141-148.

[27] Khan, R., Sadul, M.Z.H., Latif, A.A., Khan, A.U. 2011. Activity of solvent extract of prosopisspicigera, zingiber officinale and Trachy spermumammi against multidrug resistant bacterial and fungal strains. The Journal of Infection in Developing Countries, 4 (5), 292-300.

[28] Sakulpanich, A., Gritsanapan, W. 2009. Determination of anthraquinone glycoside content in Cassia fistula leaf extracts for alternative source of laxative drug. International Journal of Pharma and Bio Sciences, 3 (1), 42-45.

[29] Guhabakshi, D.N., Sensarma, P., Pal, D.C. 2001. A Lexicon Medicinal Plants of India. Naya Prakashan Calcutta India, 135-136.

[30] Singh, R., Singh, N., Saini, B.S., Rao, H.S. 2008. In vitro antioxidant activity of pet ether extract of black pepper. Indian Journal of Pharmacology, 40 (4), 147-151.

[31] Zhang, J., Zhang, C., Chen, H., Fu, L., Tao, Y., Zhang, X., Cao, Z., Zhong, Y., $\mathrm{Yu}, \mathrm{L}$. 2010. Assignment of $\mathrm{H}$ and $\mathrm{L}_{1}$ and investigation of anticancer activity in vitro. Journal of Medicinal Plants Research, 4 (4), 335-338.

[32] Sreepriya, M., Bali, G. 2006. Chemopreventive effects of embelin andcurcumin against N-nitrosodiethylamine/phenobarbitalinducedhepato-carcinogenesis in Wistar rats. Fitoterapia, 76 (6), 549-456.

[33] Parveen, N., Aleem, S., Latafat, T. 2004. A clinical study on role of Qurs Deedan and its efficacy in Ascaris lumbricoides. Hamdard Medicus, 47 (2), 69-72.

[34] Guglielmo, C.G., Piersma, T., Williams, T.D. 2001. A sportphysiological perspective on bird migration: evidence for flight-induced muscle damage. Journal of Experimental Biology, 204 (15), 2683-2690.

[35] Satheesh, M.A., Pari, L. 2004. Antioxidant effect of Boehavia diffusa L in tissues of alloxau - induced diabetic rats. Indian Journal of Experimental Biology, 42, 982-992.

[36] Bhandari, U., Kanojia, R., Pillai, K.K. 2002. Effect of ethanolic extract of Embelia ribes on dyslipidemia in diabetic rats. International Journal of Experimental Diabetes Research, 3, 159-62.

[37] Damanhouri, Z.A., Ahmad, A. 2014. A review on therapeutic potential of piper nigrum L. (black pepper): the king of spices. Medicinal and Aromatic Plants, 3, 161

[38] Manoj, P., Soniya, E.V., Banerjee, N.S., Ravichandran, P. 2004. Recent studies on well-known spice, Piper longum L. Natural Product Radiance, 3 (4), 222-227.

[39] Parthasarathy, U., Saji, K.V., Javarian, K., Parthasarthy, V.A. 2006. Biodiversity of Piper in South India application of GIS and cluster analysis. Current Science Bangalore, 91 (5), 652-658.

[40] Kaefer, C.M., Milner, J.A. 2008. The role of herbs and spices in cancer prevention. The Journal of Nutritional Biochemistry, 19, 347-361.

[41] Suhaj, M. 2006. Spice antioxidants isolation and their antiradical activity: a review. Journal Food Composition Analysis, 19, 531-537.

[42] Al-Mofleh, I.A., Alhaider, A.A., Mossa, J.S., Al-Sohaibani, M.O., Rafatullah, S., Qureshi, S. 2005. Inhibition of gastric mucosal damage by Piper nigrum pretretment in wistar albino rats. Pharmacognosy Magazine, $1,64-68$.

[43] Srinivasan, K. 2005. Spices as influencers of body metabolism: an overview of three decades of research. Food Research International, 38 77-86. 
[44] Karsha, P.V., Lakshmi, O.B. 2010. Antibacterial activity of black pepper (Piper nigrum L.) with special reference to its mode of action on bacteria. Journal of Asian Natural Products Research, 1 (2), 213-215.

[45] Platel, K., Sirivansan, K. 2000. Influence of dietary spices and their principles on pancreatic digestive enzymes in albino rats. Food / Nahrung, 44 (1), 42-46.

[46] Ahmed, O.M., Moneim, A.D., Yazid, I.A., Moawad, A. 2010. Antihyperglycemic, antihyperlipidemic andantioxidant effects and the probable mechanisms of action of Ruta graveolens infusion and rutin in nicotinamide-streptozocin-induced diabetic rats. Diabetologia Croatica, 39 (1), 15-35.

[47] Khajuria, A., Thusu, N., Zuthshi, U. 2002. Piperine modulates permeability characteristics of intestine by inducing alteration in membrane dynamics: influence on brush boarder membrane fluidity, ultrastructure and enzyme kinetics. Journal of Phytomedicine and Therapeutics, 9, 224-231.

[48] Mensor, L.L., Menezes, F.S., Leitao, G.G., Reis, A.S., Dos-Santos, T.S., Coube, C.S., Leitao, S.G. 2001. Screening of Brazilian plant extracts for antioxidant activity by the use of DPPH free radical method. Phytotherapy Research, 15 (2), 127-130.

[49] Kaleem, M., Sarmad, H.S., Bano, B. 2005. Protective effects of Piper nigrum and Vinkarosea in alloxan induced diabeteic rats. Indian Journal of Physiology and Pharmacology, 49 (1), 65-71.

[50] Lobster, M. 2002. Delmar's Integrative Herb Guide for Nurses. Thomson Delmar's Learning, Albany, 2 (8), 360-370.

[51] Boskabady, H.M., Kiani, S., Rakhshandahim, H. 2006. Relaxant effects of Rosa damascena on guineapig tracheal chains and its possible mechanisms. Pharmaceutical Chemistry, 106, 377-382.

[52] Alam, M.A., Nyeem, M.A.B., Awal, M.A., Mostofa, M., Alam, M.S., Subhan, N., Mostfizur, M. 2011. Antioxidant and hepatoprotective action of the crude ethanolic extract of the flowering top of Rosa damascene. Journal of Pharmacology and Experimental Therapeutics, 8 (2), 164-170.

[53] Shohayeb, M., Sayed, S.A., Hameed, A., Bazaid, S.A., Maghrabi, I. 2014. Antibacterial and antifungal activity of Rosa damascena Mill. Essential oil, different extracts of rose petals. Global Journal of Pharmacology, 8, 01-07.

[54] Gangadhar, K., Patwari, S., Verma, A., Kaviyarasy. 2012. Megalencephalic Leukoencephalopathy with Subcortical Cyst: A Case Report. New Jersey Resoures, 2 (2), 76-80.

[55] Sabu, M.C., Kuttan, R. 2009. Anti-diabetic and antioxidant activity of Terminalia belerica Roxb. Indian Journal of Experimental Biology, 47, 270275.

[56] Gupta, P., Mahla, J., Gupta, Y.K. 2012. Antiobesity effect of safoof mohazzil, a poly herbal formulation, in cafeteria diet induced obesity in rats. Indian Journal of Experimental Biology, 50, 776-784.
[57] Ansari, L.M.A., Kickler, T.S., Borowitz, M.J. 2009. Immature granulocyte measurement using the Sysmex XE-2100. Relationship to infection and sepsis. American Journal Clinical Pathology, 120 (5), 795799.

[58] Moghimipour, H., Handali, S. 2015. Saponin: properties, methods of evaluation and applications. Sci. Domain. Intro., 5 (3), 207-220.

[59] Malekzadeh, F., Ehsanifar, H., Shahamat, M., Levin, M., Colwell, R.R. 2001. Antibacterial activity of black myrobalan (Terminalia chebula Retz) against Helicobactor pyloli. International Journal of Antimicrobial Agents $18,85-88$.

[60] Lee, C.K., Moon, K.H., Shun, K.H. 2005. Screening and isolation of antibiotic resistance inhibitors from herb material resistance inhibition of volatile components of Korean aromatic herb. Archives of Pharmacal Research, 21, 62-67.

[61] Shukla, Y., Singh, M. 2006. Cancer preventive properties of ginger: A brief review. Food Chemical Toxicology, 45 (5), 683-690.

[62] Ali, B.H., Blunden, G., Tanira, M.O., Nemmar, A. 2008. Some phytochemical, pharmacological and toxicological properties of ginger (Zingiber officinale Roscoe): A review of recent research. Food Chemical Toxicology, 46, 409-420.

[63] Gatoi, S.H., Kikuchi, A., Yi, S.S., Naing, K.W., Yamanaka, S., Watanabe, J.A., Watanabe, K.N. 2006. Use of rice SSR markers as RAPD markers for genetic diversity analysis in zingiberaceae. Japan Society Breeding, 56, 107-111.

[64] Tapsell, L.C., Hemphill, I., Cobiac, L., Patch, C.S., Sullivan, D.R., Fenech, M., Roodenrys, S., Keogh, J.B., Clifton, P.M., Williams, P.G., Fazio, V.A., Inge, K.E. 2006. Health benefits of herbs and spices: the past, the present, the future. The Medical Journal of Australia, 185 (4), 4-24.

[65] Wang, W.H., Wang, Z.M. 2005. Studies of commonly used traditiona medicine Ginger. Zhongguo Zhong Yao Za Zhi, 30 (20), 1569-1573.

[66] Thakur, H. 2014. Antimicrobial and antifungal activity of Cucumis melo L, (Cucurbitaceae) Pregularia daemina frosk (Asclepiadaceae) and ethnomedicinal plants. International Journal of Biology, 4 (1), 3661-3665.

[67] Ghayur, N.M., Gilani, A.H. 2005. Pharmacological basis for the medicinal use of ginger in gastrointestinal disorders. Digestive Diseases Sciences, 50 (10), 1889-1897.

[68] Thomson, M., Al-Qattan, K.K., Al-Sawan, S.M., Alnaqeeb, M.A., Khan, I., Ali, M. 2002. The use of ginger (Zingiber officinale Rosc.) as a potential anti-inflammatory and antithrombotic agent. Prostaglandins Leukotrienes Essential Fatty Acid, 67, 475-478.

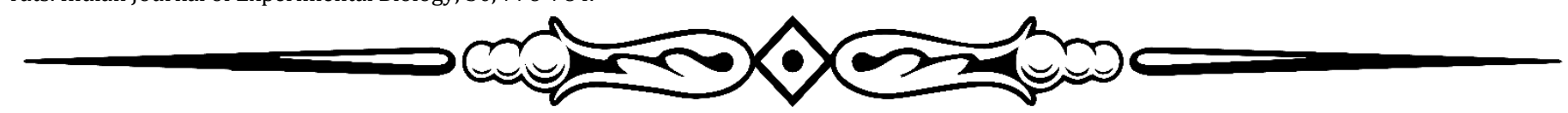

